\title{
Identification of Annual Work Hour Elements in Production Cycle and Experimental Assessment of Flow Coefficient and Optimal Series
}

\author{
Sanja STANISAVLJEV, Milivoj KLARIN, Vesna SPASOJEVIĆ-BRKIĆ, Miroslav RADOJIČIĆ, Jasmina VESIĆ-VASOVIĆ
}

\begin{abstract}
In the metalwork production a large part of gross domestic product is being achieved by automating the production in large factories, the finalists, but even a larger part comes from subcontractors and companies that have small-scale and mass production of maintenance elements and other services. Therefore, the production with higher degree of stochastics and organization mostly occurs during the production, and it happens, but to a lesser extent, that everything is planned and set in advance, and according to those facts this survey is going to analyze one of the most important production indicators - the production cycle. In this paper we are experimentally demonstrating the original stochastic method of determining 10 different production cycle working hours, and production cycle itself is determined out of factory driving records. The research also enables determining the flow coefficient which represents the function between the size of the series and technological or real time of the production cycle. Within the framework of a broader research we are contributing results of four years long record, from 2011 to 2014 for a large company with high level of organization. The production cycle per years (2011-2014) amounts to $326,233,248$ and 236 minutes, while the flow coefficient is $K p=(277 / x+0.24)$ the one that enables and experimentally determines optimal series which is in total 9 items for the company in question.
\end{abstract}

Keywords: batch sizing; flow coefficient; production cycle; stochastic model

\section{INTRODUCTION}

This paper aims to track the time elements using the modified method - work sampling which is described in detail in [1], and which differentiates from the original work sampling method, applied firstly by Tippett (1936) in the textile industry in England in such a way that in the metalwork production we have stochastic dependency according to the normal distribution law where with a large number of separate working elements, and Tippet's method according to binomial distribution law (that is questionable in practice) the machine operates for only three possible elements of working time $(+, x,-)$.

The difference is that with production cycle (PC) the product goes through the plant, and with Tippet the machine produces it's in place.

The PC division with elements of time of work that we apply herein is given in Fig. 1.

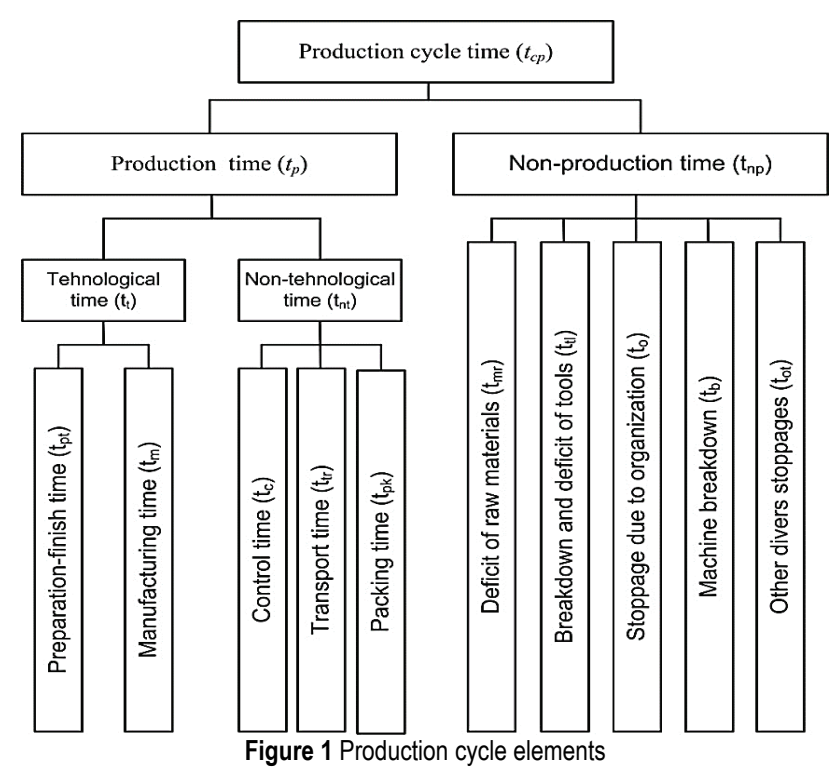

Screening performance requires the definition not only of technological and mathematical problems, but also of the practical screening process and the establishment of working time elements. Thereafter, the elements of production cycle working time should be defined and, in particular, the difference when compared with the elements of working time related to machinery, i.e. for the purpose of establishing the machine capacity only or within the production cycle, because these two differ. The elements of working time are determined according to authors $[2 \div 8]$ and may be serial, parallel or combined.

Theoretical and practical studies have shown increasing interest in using different methods and techniques in solving the problem of shortening duration of production cycle $[8 \div 18]$.

The subjected company in this survey is under German ownership with good organization, operations are parallel but on a lower level operation is of a consecutive type with all its shortcomings given in Fig. 2.

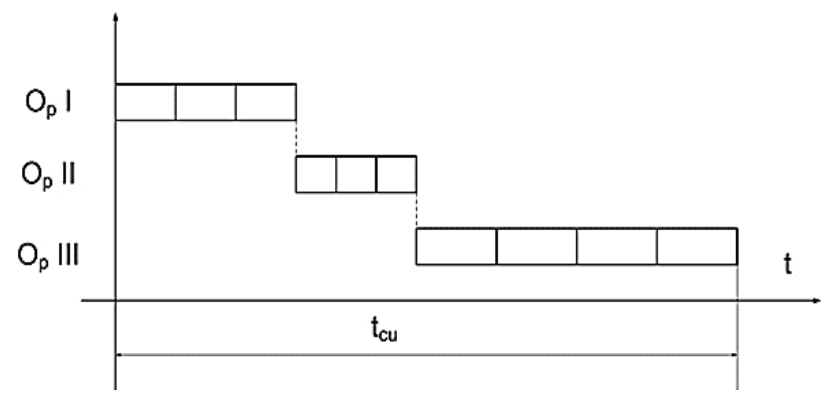

Figure 2 Organization of a consecutive type of operations sequence

The representativeness of the screening sample per number and time of screening was established by mathematical parameters, SD and control limits, where the elements of PC time are observed as the elements of the process function.

\section{APPLICATION OF THE MODEL FOR THE STOCHASTIC DETERMINATION OF PRODUCTION CYCLE TIME ELEMENTS}

The screenings were performed from September to November. The production program was not changed 
during the period of four years since we got the sample size together with representativeness.

The screenings sheet is related to one $\mathrm{PC}$, and the number of individual elements of work i.e. the frequencies are recorded on it. Using the frequencies, we first calculate the percentage of the individual elements against the total PC time, and then based on the analytical screening of the PC time duration, the time duration of individual elements of working time is calculated.

\section{RESULTS AND DISCUSSION}

Production cycle time per item and series for the year 2014 for the representative German factory that works in Serbia is given in Tab. 1.

The recorded results for each year are grouped in tables and diagrams according to elements of production cycle time of work in percentage and minutes, and according to number of items in series in minutes. The overall results in four years time are given in Tab. 2.

For easier understanding of this work we will first give an example for the movement of the productive time with controlling limits only for the year 2014, as shown in diagram in Fig. 3 and with performed estimation in Tab. 1 with Fig. 4. Results and methodology from this work were published in [3].

All cycle results, according to the working time elements individually and in total, according to production cycles in percentages (\%) and in minutes on yearly basis are given in Tab. 2, and in Tab. 3 is given the average production cycle, estimation by the recorded time, the average production time per cycle and per item in a series per minute and production time with controlling limits and SD in percentage for years 2011, 2012, 2013, 2014, 2015 and 2016. We are representing the estimation example per cycles for the year 2014 for the productive time in diagram in Fig. 3 and Tab. 1 and in diagram in Fig. 4.

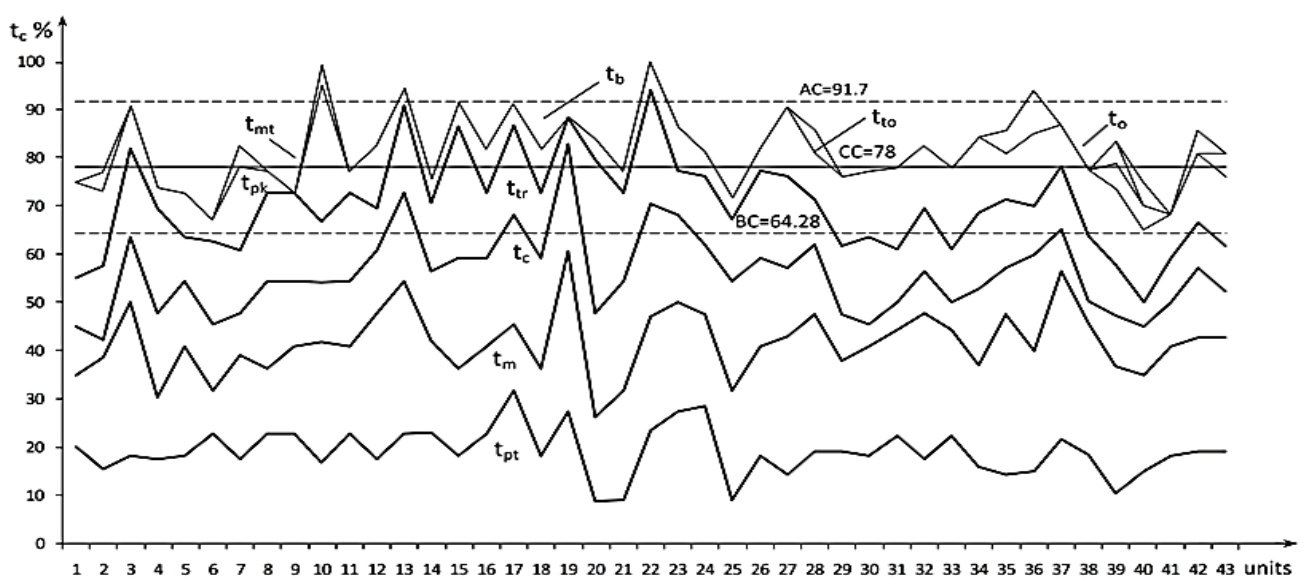

Figure 3 Movement of production cycle time elements for the year 2014

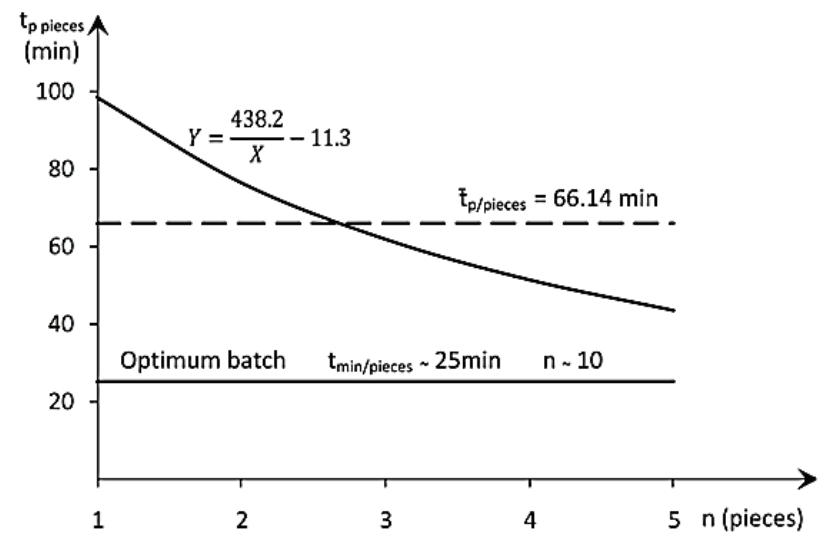

Figure 4 The movement of serial average time per number of items for the year 2014

The diagram in Fig. 3 shows that there are significant fluctuations in times of some of the time elements of PC depending on cycle, so we have some kind of saw tooth diagram. The average production time is in total $78 \% \mathrm{PC}$ or 263 minutes per cycle given in Tab. 2 , and control limits are top $A C=91.7$ and bottom $B C=64.28$.

The top limit is cut by two points of cycle, 13 and 22, although they are calculated with $\pm 3 \mathrm{SD} ; K G=77.98 \pm$ $3 \cdot 77.98 \cdot 0.0878$. The highest amount of time is manufacturing time $t_{\mathrm{m}}=22.4 \%$ and per cycle is in total $t_{\mathrm{m}}$ $=76$ min. The other amounts of time are shown in Tab. 2 .
Table 1 Production cycle time per item and series for the year 2014

\begin{tabular}{|c|c|c|c|c|}
\hline & & $X$ & $Y$ & \\
\hline No & No of cycle $\left(f_{i}\right)$ & unit/ser & $t_{\mathrm{pcu}}($ unit/ser) & $\bar{t}_{\mathrm{pi}}(\%)$ \\
\hline 1 & 5 & 4 & 89.60 & 81.30 \\
\hline 2 & 19 & 5 & 67.47 & 73.70 \\
\hline 3 & 13 & 6 & 70.68 & 79.61 \\
\hline 4 & 3 & 7 & 55.43 & 76.43 \\
\hline 5 & 3 & 8 & 47.53 & 73.20 \\
\hline & & & $\bar{t}_{\mathrm{cpu}}=66.14$ & \\
\hline
\end{tabular}

Production cycle time per item and series and experimentally closely specified optimal series is derived from the flow coefficient formula for data in Tab. 1 .

$Y=a /(x+b)=438.2 /(x-11.3)$

Some most important results per cycles, per working time elements, individually and in total, per year production cycles in percentages $\%$ and in minutes are given in Tab. 2. In Tab. 3 are given the average production cycle $t_{c}$, done according to the recorded timetable, the average productive time per cycle and per item in a series per minute and production time and controlling limits and SD \% for years 2011, 2012, 2013, 2014, 2015 and 2016.

The most important indicator of the percentage of production time was the lowest in the year 2011 - 76.4\% and then with the development of the production in the 
year 2012 and 2013 it was $83.6 \%$ and $80 \%$, in 2014 due to the new operation it was $78 \%$, in 2015 was $79.31 \%$ and in 2016 was $81.2 \%$.

The most important percentage is related to manufacturing time $\mathrm{t}_{\mathrm{m}}$ in the years: $2011 .-24.6$; 2012.-25.9; 2013.-23.76 in 2014. - 22.4\%, in $2015-16.48 \%$ and in $2016 ; 16.36 \%$ at preliminary - final time in $2011-10.9$;
2012 - 16.82; 2013 - 16.5; 2014.-19\%; $2015-28.88 \%$ and $2016-29.1 \%$ which makes the total amount of technological time $t_{t}$. It can be noticed that for the metal working industry the total percentage of preliminary-final time is high, and with its decline the production cycle could be reduced.

Table 2 Operation time elements of the production cycle for 6 years

\begin{tabular}{|c|c|c|c|c|c|c|c|c|c|c|c|c|c|c|}
\hline Year & \multicolumn{2}{|c|}{2011} & \multicolumn{2}{|c|}{2012} & \multicolumn{2}{|c|}{2013} & \multirow{2}{*}{\multicolumn{2}{|c|}{$\begin{array}{c}2014 \\
43\end{array}$}} & \multicolumn{2}{|c|}{2015} & \multicolumn{2}{|c|}{2016} & \multicolumn{2}{|c|}{ 2011-2016 } \\
\hline No of cycle & \multicolumn{2}{|c|}{46} & \multicolumn{2}{|c|}{30} & \multicolumn{2}{|c|}{39} & & & \multicolumn{2}{|c|}{32} & \multicolumn{2}{|c|}{20} & \multicolumn{2}{|c|}{$\bar{x}$} \\
\hline Unit of measure & $\%$ & $\min$ & $\%$ & $\min$ & $\%$ & $\min$ & $\%$ & $\min$ & $\%$ & $\min$ & $\%$ & $\min$ & $\%$ & $\min$ \\
\hline$t_{\mathrm{pt}}$ & 24.6 & 3762 & 25.29 & 1737 & 23.73 & 2296 & 22.4 & 3254 & 16.48 & 1.695 & 16.36 & 1.052 & 21.46 & 2299 \\
\hline$t_{\mathrm{p}}(\% \min )$ & 76.4 & 11451 & 83.6 & 5820 & 79.77 & 7694 & 78 & 11301 & 79.31 & 8.158 & 81.2 & 5138 & 79.7 & 8260 \\
\hline$t_{\mathrm{np}}$ & 25.19 & 3856 & 16.4 & 1158 & 20.33 & 1968 & 22 & 3225 & 20.69 & 2.077 & 18.8 & 1189 & 20.6 & 1899 \\
\hline$t_{\mathrm{c} \min / \mathrm{cik}}$ & 100 & 326 & 100 & 233 & 100 & 248 & 100 & 338 & 100 & 3.21 & 100 & 316 & 100 & 297 \\
\hline$t_{\mathrm{p} \min / \mathrm{cik}}(\% \min / \mathrm{cik})$ & 76.4 & 249 & 83.6 & 194 & 79.77 & 193 & 78 & 263 & 79.31 & 2.55 & 81.2 & 257 & 79.7 & 235 \\
\hline$t_{\mathrm{p}} / N(\min )$ & \multicolumn{2}{|c|}{31} & \multicolumn{2}{|c|}{37.7} & \multicolumn{2}{|c|}{31.5} & \multicolumn{2}{|c|}{44.8} & 40.03 & & & 45.1 & \multicolumn{2}{|c|}{38.36} \\
\hline
\end{tabular}

Table 3 Average production cycle per cycle, average production time per cycle and item in series, in minutes, and production time and control limits in percent

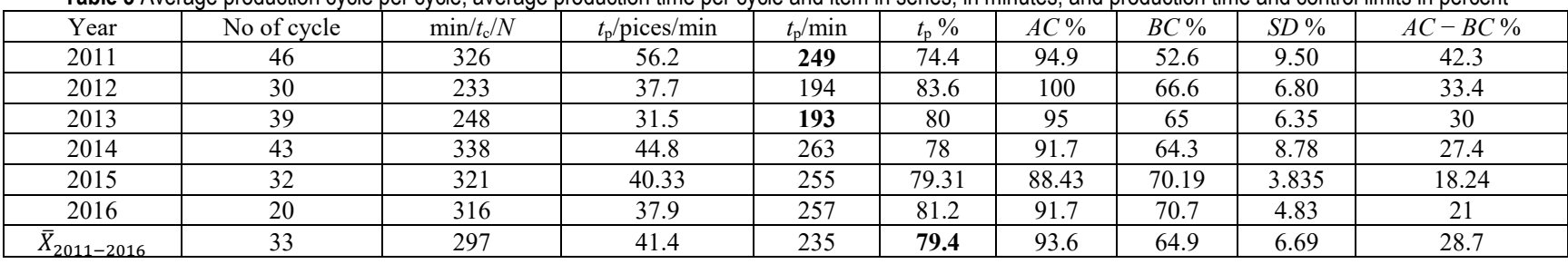

This amount of time in the year 2011 for almost the same amount of technological time $(24.6 \%$ and $23.73 \%)$, was only $10.7 \%$. The reason for this may be the fact that the factory is in the phase of expansion of its capacities, and in the phase of operation reconstruction, as well.

The average production time, in minutes, in the years $2011-2016$ was $t_{\mathrm{p}} \min =235 \mathrm{~min}$, and in percents it was $t_{\mathrm{p}} \%$ $=79.4 \%$. Non-productive time is $t_{\mathrm{np}} \min =54.8$ minutes or $t_{\mathrm{np}} \%=20.6 \%$.

Observing the Tab. 3, it can be noticed that the average production time from the year 2011 to the year 2013 has considerably decreased from $249 \mathrm{~min}(76.4 \%)$ to 193 (79.77\%) minutes. Due to the organization level rising and production development during the whole year and due to the introduction of the new operation process which lasts 30 minutes, it increased again to 263 minutes.

Inside the productive time the smallest oscillations per years are noticed with mechanical time $24.5 \%$ in 2011 , $25.29 \%$ in $2012,23.73 \%$ in $2013,22.4 \%$, in $2014,16.8 \%$ in 2015 and $16.36 \%$ in 2016 .

The movement of serial average time per number of items for the year 2014 is given in Fig. 4.

Representation and quality of the research is, besides control limits $A C$ and $B C$, standard deviation $S D$, normal distribution of work time elements movement and total amount of production time established (as given in Fig. 5), the different values of $\Delta t_{i}$ of production cycle time elements can be also seen, according to the number of records and number of cycles expressed in percents and minutes with values for four years $(n=4)$ and average values reduced to the number of cycles per years $\left(N / N_{i}\right.$, 46/159, 30/159, 39/159, 43/159). How small the differences are can be noticed in the diagram in Fig. 5, too.

This is demonstrated by representativeness because the data movement is the same per cycle per minute and in percentages.
In Fig. 6 there is shown PC time elements movement per years, and it can be noticed that there is averaging of all elements in comparison to those average elements based on the cycles given in Fig. 3, where there are considerable oscillations of PC time elements and total average production time and where the control limits are wider, since the error had to be calculated with $\pm 3 S D$, while by monitoring per years they were calculated with $\pm 2 S D ; A C$ $=93.6 \%, B C=64.9 \%$. Generally, for the production where human factor is very important it is better to have $1 / 3$ of narrower limits with $95.45 \%$ of probability, than for the small increase of probability of $99.97 \%$ (often unnecessary) to increase imprecision of control limits.

Movement of total production time $t_{\mathrm{p}}$ and per item can be seen in Tabs. 1, 2, 3 and in Fig. 7.

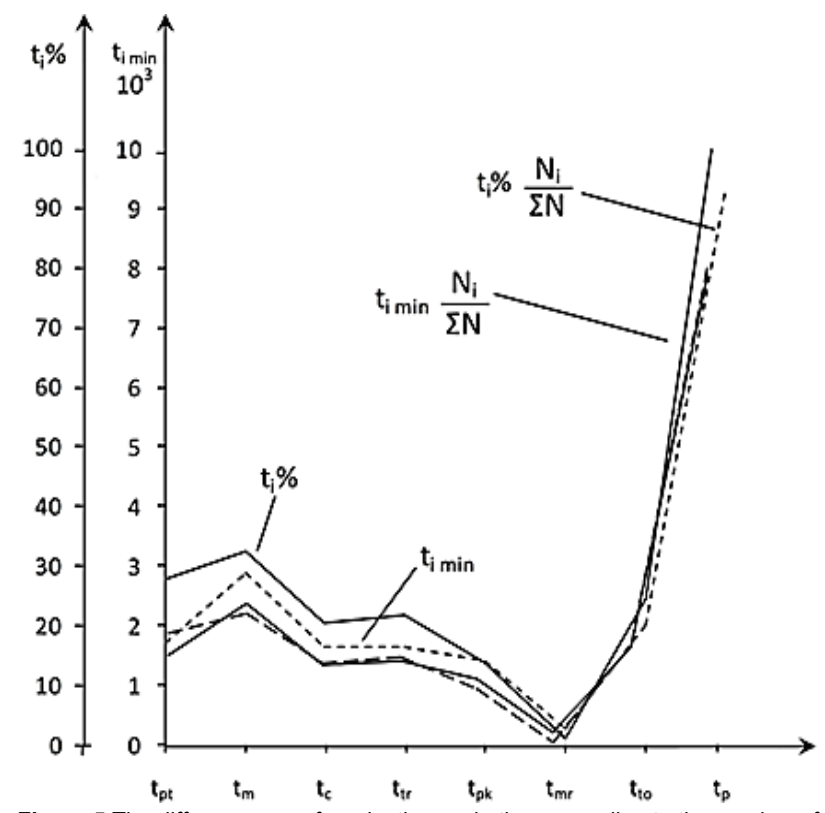

Figure 5 The difference $\Delta t_{i}$ of production cycle time according to the number of records and number of cycles (2011-2014) 

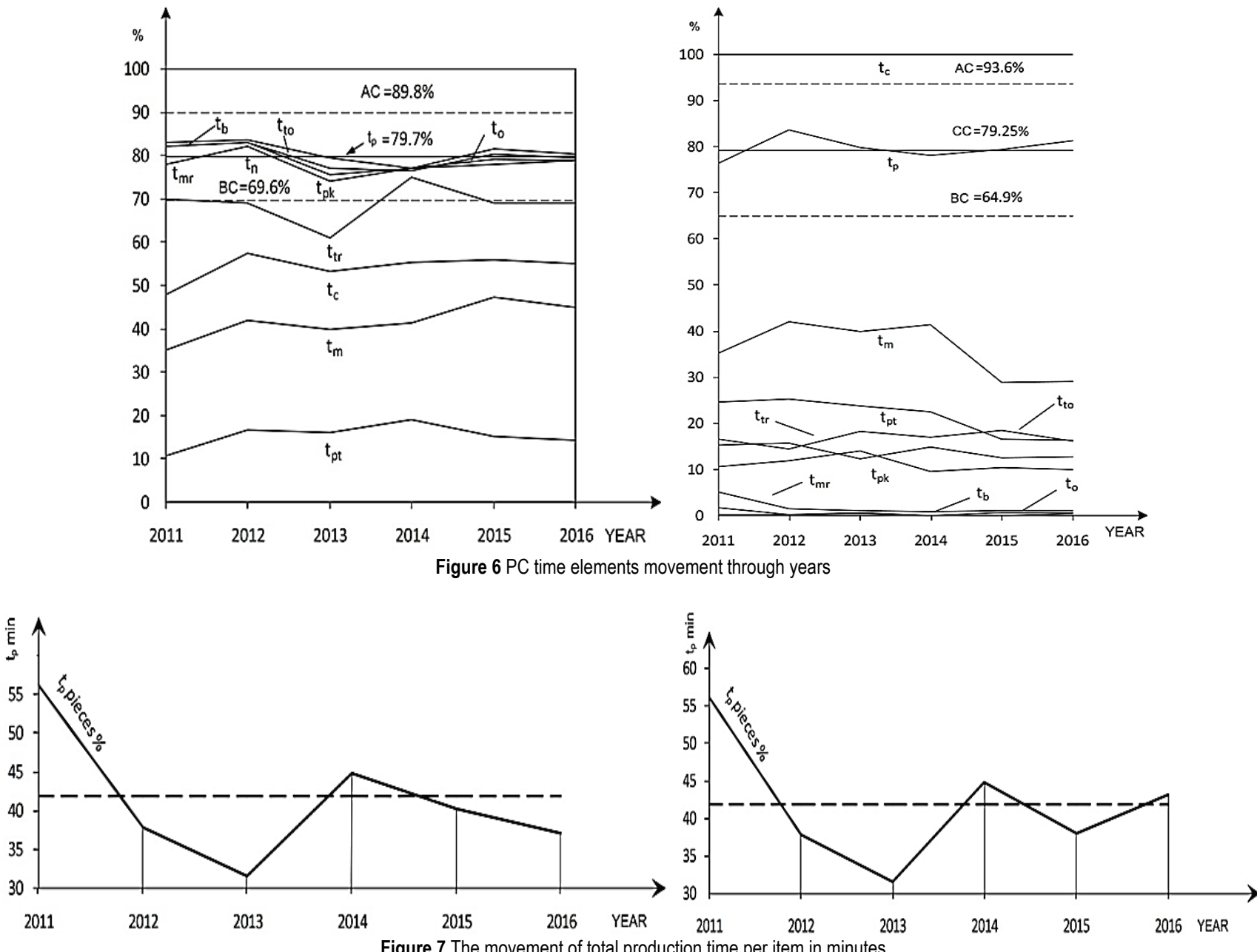

The increase in the number of pieces in the series can be seen for year 2013 - 8 pieces, for 2014 there are 10.5 pieces, for 2015 also 10.5 , for the year 2016 there are is 12 pieces. In addition, in the years 201 and 2016 there was an increase in $t_{\mathrm{m}}$, a decrease in $t_{\mathrm{pt}}$ which is due to the better organization of work and changing preparatory finishing times (Fig. 6).

There was also a decrease in production time per piece in Tab. 4 and in percentage in Fig. 8 and Fig. 9 in relation to the increase in the number of pieces in the series, which is practically the second criterion for optimizing the number of pieces.

Both functions per years have the same trend, firstly from 2011 to 2012 there is a considerable decrease, from the year $2012 t_{\text {punit }}$ in percentage continues to decrease vaguely but $t_{\min }$ increases, so that in the year 2013 there is a considerable increase again, while $t_{\text {punit }}$ percentage considerably increases, as well. Both functions could be approximated by parabola with existing minimum, which for axis of symmetry has the y axis.

According to the calculation of the flow coefficient for the whole four years using formula $Y=\frac{a}{X}+b$, based on the data from Tab. 1 and using average values for four years, the data are got according to the number of items in series in function, from the production cycle time per items in minutes.

Using normalized equations, the parameters $a$ and $b$ are obtained: $a \sum_{i=1}^{n} \frac{1}{X^{2}}+b \sum_{i=1}^{n} \frac{1}{Y}=\sum_{i=1}^{n} \frac{Y_{1}}{X}$

$a \sum_{i=1}^{n} \frac{1}{X}+N \cdot b=\sum_{i=1}^{n} Y_{1}$

$a \cdot 0.3067+b \cdot 0.2273=85$

$a \cdot 1.512+b \cdot 9=421$

$a=277, b=0.242$ and the function of flow coefficient

$Y=\frac{277}{X}+0.242$

In the diagram in Fig. 8 it can be noticed that the theoretical function has the real values with 9 points, while in the part of the last 3 points with greater deviations values are approximated, in a way that these are really the shortest periods of time per items in series with 9, 12 and 10 items, 27,28 and 27.6 minutes. In this way, the real minimum value of the function of production time per item is 9 items, while according to the theoretical function, minimum value is endless number of items in series. This is the reason for the experimental determination of optimal series, because the flow coefficient is affected by a number of factors in the production, and function value after certain minimum increases abruptly. In addition to this one, in our calculations the main criterion is production period, and the other important criteria the costs of frozen funds are not considered, which in higher level criteria analysis would be done, in future works. 
Table 4 Number of items in series with production cycle time per items, in minutes, per year: its average value

\begin{tabular}{|c|c|c|c|c|c|c|c|c|}
\hline \multirow{2}{*}{ No } & \multirow{2}{*}{$X_{n}$} & \multicolumn{6}{|c|}{$t_{p \mathrm{cn}}$} & \multirow{2}{*}{$\frac{Y}{\bar{t}_{n}}$} \\
\hline & & 2011 & 2012 & 2013 & 2014 & 2015 & 2016 & \\
\hline 1 & 3 & 93.1 & - & - & - & - & - & 93.1 \\
\hline 2 & 4 & 72.48 & 53.7 & 49 & 98.2 & - & - & 68.35 \\
\hline 3 & 5 & 63.29 & 40.5 & 39 & 76.3 & 51.51 & 53.4 & 54 \\
\hline 4 & 6 & 57.02 & 38.5 & 33 & 61.7 & 43.82 & 56.7 & 48.46 \\
\hline 5 & 7 & 43.5 & 30.1 & 28 & 51.3 & 38.32 & 36.29 & 37.92 \\
\hline 6 & 8 & 45.5 & 30.6 & 25 & 43.5 & 34.2 & 45.95 & 37.46 \\
\hline 7 & 9 & - & 31.7 & 22 & - & 31 & 38.1 & 30.7 \\
\hline 8 & 10 & 35.67 & 29 & 20 & - & 28.4 & 33.9 & 29.4 \\
\hline 9 & 11 & - & - & - & - & - & 30.82 & 30.82 \\
\hline 10 & 12 & - & 27.6 & - & - & - & & 27.6 \\
\hline$\overline{\bar{X}}$ & 41.9 & $\bar{X} 56.2$ & 37.7 & 31.5 & 44.8 & 37.9 & 43.18 & 45.8 \\
\hline
\end{tabular}
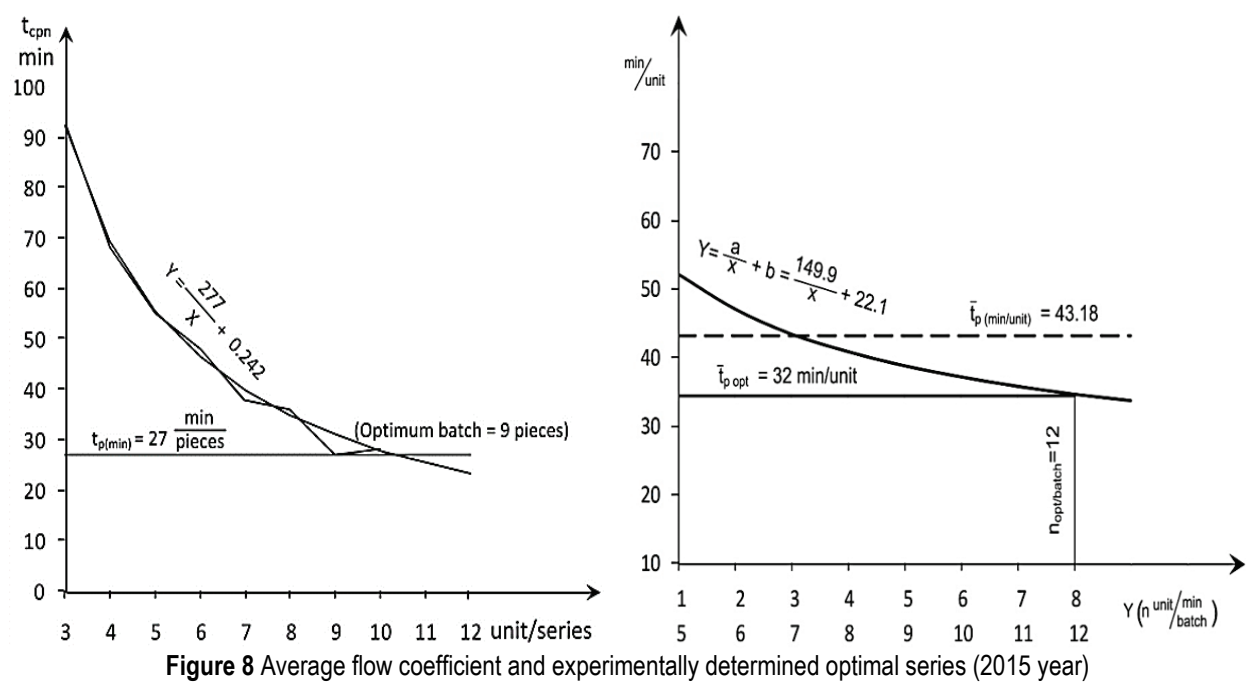

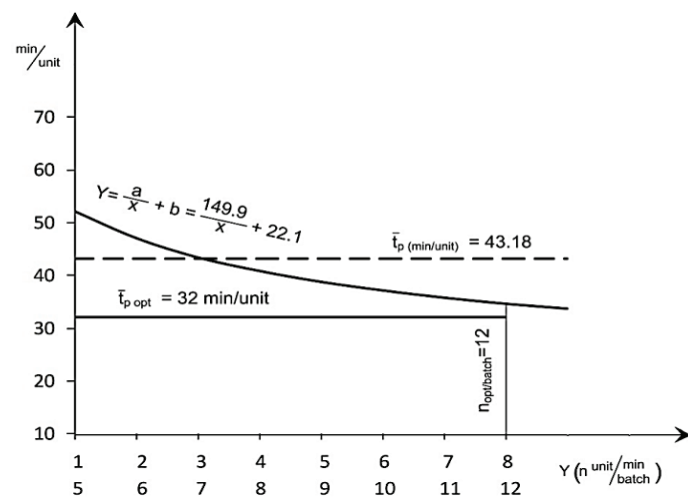

Figure 9 Average flow coefficient and experimentally determined optimal series (2016)

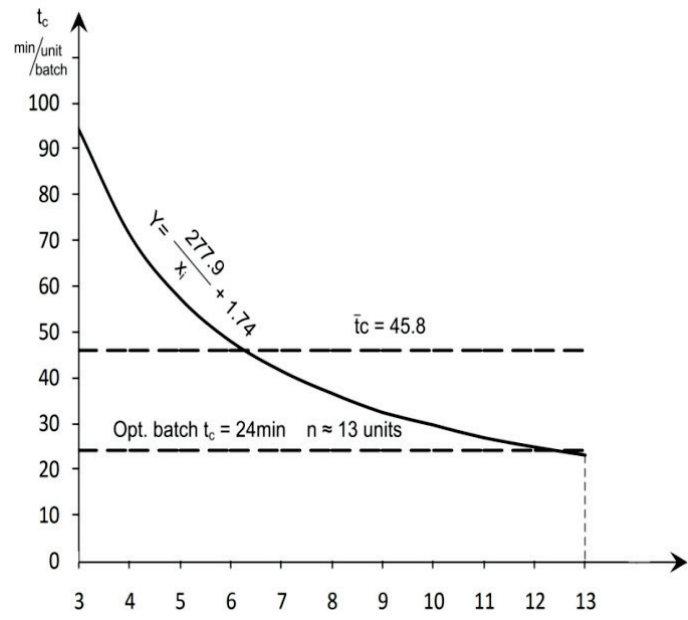

Figure 10 Average flow coefficient and experimentally determined optimal series (2011-2016)

\section{CONCLUSION}

In this paper, it is proved that it is possible to experimentally determine production cycle by modifying method of work sampling, and based on the analysis of its five work time elements, which make production time $t_{p}$ and certain number of break periods during the nonproductive time $\mathrm{t}_{\mathrm{np}}$ (in our company is 5 , as well).

Monitoring the function of time was performed by using the recorded periods of time per cycles in percentages and minutes. In production planning and production management monitoring per years is very important. Analysis has shown that the parameters of stochastic process of control limits and standard deviation representation are much preferred with monitoring per years.

By monitoring through years and cycles, values of the most important parameter of production time for 2011, 2012, 2013, 2014, 2015 and 2016 are 76.4; 83.6; 79.77, 78, 81.2 and $79.31 \%$ or the average for 6 years amounts to $79.7 \%$ with standard deviation $S D=6.69 \%$, but control limits are $C C_{2 \mathrm{SD}}=79.7 \pm 2 \cdot 79.7 \cdot 0.669=79.7 \pm 10.1$ or $C C_{3 \mathrm{SD}}=79.7 \pm 16$. This means that for greater sample size we get better precision of all parameters, which also applies to experimental determination of optimal series which is approximately 9 items in series with minimum time per item $p_{\min }=27 \mathrm{~min} /$ unit and is expressed by flow coefficient function got from average value of the data of $Y$ and $X$ for four years. 


\section{Acknowledgements}

This work was supported by the Serbian Ministry of Education and Science: Grant TR 35017.

\section{REFERENCES}

[1] Klarin, M. M., Milanović, D. D., Spasojević-Brkić, V., Misita, M., \& Jovanović, A. A. (2010).Method to assess capacity utilization in short cycle functional layouts. Journal of Process Mechanical Engineering, Part E.224 (E1). https://doi.org/10.1243/09544089JPME280

[2] Čala, I., Klarin, M., \& Radojčić, M. (2011). Development of a Stohastic model for determing the elements of production cycle time and their optimization for serial production in metal proces-sing industry and recycling processes. In processing of the International Sympo-sium Engineering Management and Competitiveness, 21-24, Technical faculty "M. Pupin", Zrenjanin, Serbia.

[3] Ćoćkalo D., Stanisavljev, S., Đorđević, D., Klarin, M., \& Brkić, A. Đ. (2014). Determination of the Elements of Production Cycle Time In Serial Production: The Serbian Case. Transaction of the Canadian Society for Mechanical Engineering, 38(3), 289-304. https://doi.org/10.1139/tcsme-2014-0021

[4] Johnson, D. J. A. (2003). Framework for reducing manufacturing throughput time. Journal of Manufacturing Systems, 22(4), 283-298. https://doi.org/10.1016/S0278-6125(03)80009-2

[5] Maynard, H. B. (1971). Industrial Engineering Handbook. Pittsburgh, PA: McGraw-Hill.

[6] Moder, J. J. (1980). Selection of work sampling observation times - Part I Stratified sampling. AIIE Transactions 12, 23 31. https://doi.org/10.1080/05695558008974486

[7] Klarin, M. M., Cvijanović, M. J., \& Spasojević-Brkić, K. V. (2000). The shift level of the utilization of capacity as the stochastic variable in work sampling. International Journal of Production Research, 38(12), 2643-2651. https://doi.org/10.1080/002075400411402

[8] Klarin, M. M., Spasojević-Brkić, V., Golubović, T., Stanisavljev, M. S., Brkić, A., \& Sajfert, Z. (2016). Production cycle time reduction in low and medium-lowtech companies: a case study for Serbia. Tehnički vjesnik, 23(4), 1103-1108. https://doi.org/10.17559/TV-20140715130015

[9] Agrawal, A., Minis, I., \& Nagi, R. (2000). Cycle time reduction by improved MPR - based production planning. International Journal of Production Research, 38(18), 48234841. https://doi.org/10.1080/00207540050205659

[10] Aouam, T. \& Uzsoy, R. (2014). Zero-order production planning models with stochastic demand and workloaddependent lead times. International Journal of Production Research, 53(6), 1661-1679. https://doi.org/10.1080/00207543.2014.935514

[11] Bhat, Sh. (2008). Improve profits and reduce cycle time with manufacturing cells. Advances in Production Engineering \& Management, 3(1), 17-26.

[12] Galante, G. \& Passannanti, G. (2006). Minimizing the cycle time in serial manufacturing systems with multiple dualgripper robots. International Journal of Production Research, 44(4), 639-652. https://doi.org/10.1080/00207540500337544

[13] Giri, B. C. \& Yun, W. Y. (2005). Optimal lot sizing for an unreliable production system under partial backlogging and at most two failures in a production cycle. International Journal of Production Economics, 95, 229-243. https://doi.org/10.1016/j.jpe.2004.01.004

[14] Huang, J. Y. \& Yao, M. J. (2013). On the optimal lot-sizing and scheduling problem in serial-type supply chain system using a time-varying lot-sizing policy. International Journal of Production Research, 51(3), 735-750. https://doi.org/10.1080/00207543.2012.662604

[15] Mula, J., Poler, R., Garcia-Sabater, J. P., \& Lario, F. C. (2006). Models for production planning under uncertainty. International Journal of Production Economics, 103(1), 271-285. https://doi.org/10.1016/j.jpe.2005.09.001

[16] Radojicic, M., Nesic, Z., Vesic-Vasovic, J., Klarin, M., \& Spasojevic-Brkic, K. V. (2011). One approach to improving production capacities in the function of reducing the cost. Technics Technologies Education Management, 6(4), 13281334.

[17] Vesic-Vasovic, J., Radojicic, M., Klarin, M., \& SpasojevicBrkic, K.V. (2011). Multi-criteria approach to optimization of enterprise production programme. Proceedings of the Institution of Mechanical Engineers, Part B - Journal of Engineering Manufacture, 225(10), 1951-1963. https://doi.org/10.1177/0954405410397433

[18] Tzu-Hsien, L. (2009). Optimal production run length and maintenance schedule for a deteriorating production system. The International Journal of Advanced Manufacturing, 43, 959-963. https://doi.org/10.1007/s00170-008-1773-1

\section{Contact information:}

Sanja STANISAVLJEV, PhD, Assistant Professor University of Novi Sad, Technical faculty "Mihajlo Pupin", Đure Đakovića bb, 23000 Zrenjanin, Serbia

E-mail: sanja.stanisavljev@tfzr.rs

Milivoj KLARIN, PhD, Professor

University of Novi Sad, Technical faculty "Mihajlo Pupin", Đure Đakovića bb, 23000 Zrenjanin, Serbia

E-mail:mklarin@open.telekom.rs

Vesna SPASOJEVIĆ-BRKIĆ, PhD, Professor

University of Belgrade, Faculty of Mechanical Engineering,

Kraljice Marije 16, 11000 Beograd, Serbia

E-mail: vspasojevic@mas.bg.ac.rs

Miroslav RADOJIČIĆ, PhD, Professor

Faculty of Technical Sciences Čačak, University of Kragujevac,

Svetog Save 65, 32102 Čačak, Serbia

E-mail: miskoradojicic@gmail.com

Jasmina VESIĆ-VASOVIĆ, PhD, Professor

Faculty of Technical Sciences Čačak, University of Kragujevac

Svetog Save 65, 32102 Čačak, Serbia

E-mail: jasmina.vesic@gmail.com 